generally like to use them except for killing small game, as they often broke, and they have told me that their boomerangs were not 'strong enough' to kill a man. For fighting they have no throwing weapons--no throwing-sticks for their spears, but throw them by the hand, and only do so in extremity, for the spear is too valuable a weapon. It is only used as a pike; and they obtain their spears by barter from some tribe to the north. In ordinary fighting they use a weapon like a boomerang from 4 to 5 feet in length. It is held in both hands and blows are struck with the convex edge. They were not warded off when I saw it used, but the blows were struck indiscriminately -a sort of free fight. These weapons are made by themselves of boxwood.

"In throwing the boomerang I have seen it usually beld nearly parallel with the horizon. When thus thrown it would rise and return towards the thrower, but the blackfellows always told me that al though they could ensure its returning near them they could not tell exactly where it would come to. They could tell the direction but not the distance. If the boomerang strikes anything its course ceases.

"Some years ago the blackfellows living in the mountains just south of Blanchewater had no boomerangs and no spears. Their weapons were yamsticks and stones. They had no shields. Boomerangs, spears, and shields were acquired by them from the Blanchewater blacks, in return for which they bartered Wallaby rugs; at that time the Blanchewater and Deerie blacks had absolutely no clothing.

"This system of barter is said to have been instituted by a $\mathrm{Hil}$ blackfellow named Pompey, who, in 1856 , was concerned in the spearing of two men at Angepina. He escaped and went north to the Deerie blacks, having first stayed some time with the Blanchewater blacks, who understood both languages, being a border tribe. He took up to the Deerie blacks some flour, sugar, tobacco, and for some time settled at Kopparamanna. He endeavoured to raise a confederacy to drive the white settler out of the Flinders Range, and is said at that time to have instituted the system of barter.

"I knew this Pompey in 1857, when he sent another blackfellow, named Blanchewater Charley, to offer his services as 'nauto shepherd.' When Pompey then came in he told me much of the above concerning himself, which was also current ameng the tribes. He was a very shrewd fellow, and thus became a leader among them. He was afterwards shot for killing stationblacks. The national weapons of the Blanchewater blacks are stones. These are thrown of the size of the fist, and are perhaps thrown as far as a hundred yards, and with precision for forty yards; and in throwing, a rotatory motion is imparted to the stone. At about forty to fifty yards they can hit a smal mark, such as a bottle, almost without fail. In fighting at close quarters they ward off spear blows by means of a short stick held in the hand, and if possible, in cases where the spear has been thrown, clutching it in passing with the other. They do not use a shield for stopping spears, but against stones, which, as I have said, are the national weapons."

Although much of the above cannot be said to be strictly belonging to the "boomerang," I have preferred to give $\mathrm{Mr}$ James's statements in full as given to me.

Much that he says corroborates the statements I have made in the letter referred to.

It is much to be regretted that no one else than myself among your readers in Australia has recorded their observations on the "boomerang," in reply to your correspondent's request.

$$
\text { Bairnsdale, Gippsland, Victoria A. W. Howitr }
$$

\section{Longmynd Rocks}

Mr. H. B. Woobward, in his "Geology of England and Wales," p. 28, states that, near Shrewsbury, the Longmynd Rocks are overlaid conformably by the Lingula Flags. I should be glad to see the evidence upon which this conclusion is based So far as $I$ have examined the district, the facts do not sustain Mr. Woodward's view. Arenig fossils are found at the very head of the ravines which cut back nearly to the quartzite of the Stiper Stones. The beds under the quartzite are similar in lithological character to the Arenig shales above, and I have not heard of the lower shales yielding lingula flag fossils. At the base of the escarpment is the fault which separates the Stiper Stones rocks from the Longmynd beds. I believe the Stiper Stones beds are Arenig, in the absence of proof to the contrary. The quartzose band of the Stiper Stones may represent the arenaceous bed adopted by the Geological Survey as the base of the Arenig.

Wellington, Salop, January is
The Measurement of the Height of Clouds

IT has always been a matter of some interest to obtain measures of the height of clouds, independently of observations made from balloons or on mountains.

During last July and August I made a series of measures of cloud-altitudes--the first, I believe, of their kind-by photographing the clouds simultaneously from different stations.

The details of the process would occupy too much space to be inserted here, but I have reason to believe that the results obtained are not as much as three per cent. in error. The cirrus clouds which I measured varied in height from 22,000 to 25,000 feet ; massive cumuli from 6,000 to 7,000 feet. I did not get any good examples of cirro-cumulus or stratus. Rain-clouds appeared at all altitudes up to 4,000 feet. I hope to resume the measures at some future time.

Terling Place, Witham

\section{Mimetic Habit of Bats}

IN September, 1875, whilst paddling in a dorey (dug ou boat) through a narrow and dark creek leading from Belize River, Honduras, to Reid's lagoon, we disturbed a number of small bats which were clinging to the trunks and branches of the mangroves overhanging the water. These bats were about six inches in expanse and of a grey colour so exactly corresponding with that of the trees on which they settled as to be with diff culty distinguishable even at a distance of only a few feet. They invariably clung to the trunk or bough with wings expanded, and were never, so far as I noticed, suspended from the branches.

I saw the same species in Black Creek of the same river in February last year clinging to the trees in a similar manner, and conclude it is the natural position of the animal when at rest. I send this note as I do not recollect having anywhere seen this curious mimetic resemblance and peculiar habit ramarked upon. IOI, Grove Street, Liverpool, January 22 S. ARCHER

\section{THE SPONTANEOUS GENERATION QUESTION}

THE following paper on this subject was read at the Paris Academy oi Sciences on January $8^{3}:-$

The Academy has perhaps not forgotten that at the seidnce of July Io last, Dr. Bastian announced the discovery by him of the physico-chemical conditions necessary and sufficient for the spontaneous generation of certain varieties of microscopic objects of the genus Bacteria. The experiment which, according to Dr. Bastian, realises these conditions is very simple ; it consists in exactly neutralising by liquor potasse urine deprived of every organic germ and exposing the mixture to a temperature of fifty degrees. In those conditions certain varieties of bacteria promptly appeared.

Dr. Bastian has no doubt as to the bearing of his conclusions. To all who are attentive to medical movements it is evident that the debate relative to spontaneous generation has been removed into the domain of the etiology of contagious diseases.

I immediately repeated the experiment, and I proved, among other things, that it is sufficient to determine the saturation of the urine by solid potash instead of potash in aqueous solution (which does not modify whatever be the physico-chemical conditions to which it is subjected) for the mixture to remain perfectly sterile. I hence concluded that the interpretation given by Dr. Bastian to his experiment was totally inadmissible

Dr. Bastian replied (Comptes Rendus, July $3 \mathrm{I}$ and August 2I) he did not at all dispute the legitimacy of my reasoning, but he affirmed that I reproduced his experiment badly and exceeded the exact point of neutralisation of the urine. Such is, according to him, the cause of the sterility of the liquid in my hands.

The question is then limited to the point: Have I done any thing else but replace the liquor potasse by melted potash, and specially, have I exceeded the point of saturation of the urine, and is there anything amiss in so doing?

I have examined the debate reduced to these terms, along with M. Joubert, with all the attention of which we are both of us capable, and we are able to declare to the Academy, on the basis of new experiments, that the exact neutralisation of the urine by solid potash, which we had melted, left the urine sterile. We add, although that may not be indispensable, that there is no obstacle to the fertilisation of urine, in the experi-

r Continued from p. 303

2 Note on the Alteration of Urine in reference to Recent Communications of Dr. Bastian, by MM. Pasteur and Joubert. 
ment of Dr. Bastian, in exceeding the point of saturation, even sensibly. ${ }^{1}$

The conclusion of my reply of July in last is then unassailable, consequently it is not accurate that Dr. Bastian has found the physica-chemical conditions for the spontaneous generation of bacteria.

We have examined experimentally, with not less attention, all the other points treated by Dr. Bastian in his papers of July 3I and August 2I, subsequent to his original note of July ro. We are prepared to discuss them, but as they might distract attention from the main point of the debate we shall return to them later if convenient. One thing is of importance at the present moment, to know if Dr. Bastian is still convinced that urine, exactly neutralised by potash, yields microscopic organisms.

What we have said on the influence of solid potash may be repeated for liquor potassæ after it has been raised to $110^{\circ}$. But we wish to reply to-day to Dr. Bastian solely by the facts relative to solid potash, which suffice by themselves alone to condemn the conclusions which he has deduced from his experiments.

The reader will doubtless remark that in the preceding abstract we have scrupulously avoided introducing the word germ and opposing a doctrine to a doctrine. We have to do with a fact : Yes or no, does urine which has been boiled so as to be sterile, and better still, fresh, natural urine, just from the bladder, not having been submitted to any preliminary boiling-does this at $50^{\circ}$ yield organisms after having been neutralised by potash ? Dr. Bastian says yes, and this is his pretended great discovery. We say no, and we demonstrate by proving that Dr. Bastian would have obtained a result absolutely contrary to that which he published if he had made use of the substance $\mathrm{KO}, \mathrm{HO}$, which alone, in cases when it is pure or only associated with mineral matters in small quantity, has the exclusive right of being called potash.

The following reply to the above by Dr. Bastian was read at the Paris Academy, January $22^{2}:-$

At the séance of the Academy of January $8 \mathrm{M}$. Pasteur, in conjunction with M. Joubert, contributed another "Note sur l'Altération de l'Urine," in reply to the last communication which I had the honour of submitting to the Academy at its séance of August 21 of last year.

It may, perhaps, be permitted to me to state that an account of my researches on the fermentation of urine, much fuller than what has appeared in the Comptes Rendus, is now to be found in the Proceedings of the Royal Society No. 172, 1876; and to this paper I would particularly call the attention of all those who are interested in the question of the mode of origin of Bacteria and other related problems.

I have found, as stated in an earlier communication to the Academy, that previously sterile urine, when exactly neutralised by boiled liquor potassæ (of the British Pharmacopcia) will rapidly ferment and swarm with Bacteria, if the mixed fluids are maintained at a temperature of $50^{\circ} \mathrm{C}$. M. Pasteur, after repeating my experiments with certain variations, said (Compt. Rend., July I7, p. I78): "Je m'empresse de déclarer que les expériences de $M$. le Dr. Bastian sont, en effet, très-exactes; elles donnent le plus souvent les résultats qu'il indique." He then explains why he differs from me as regards the interpretation of these experimental results. It is somewhat confusing, therefore, to find M. Pasteur now saying in his most recent communication: " une seule chose importe en ce moment, c'est de savoir si le Dr. Bastian est toujours convaincu que l'urine neutralisée exactement par la potasse donne des organismes microscopiques?" My reply is simple. M. Pasteur has implied (loc. cit. p. I 79) that solid potash heated only to $100^{\circ} \mathrm{C}$. does lead to such an effect; I, however, have made no experiments with solid potash, though, in operating with the boiled liquor potass already named, I have many times obtained the result indicated, and am quite prepared to demonstrate to others the fact of the occurrence of fermentation in urine under these conditions.

In using solid potash M. Pasteur departed from the conditions of my experiments in a way which was wholly needless. It will be found much more convenient for others to repeat them exactly. Seeing that a strong solution of potash in suitable quantity can be easily heated in a closed glass tube to the temperature which

$x$ It is not useless to say here that, contrary to what is generally admitted, urea in aqueous solution or in urine is decomposed at $100^{\circ} \mathrm{C}$. and even at temperatures much lower. The product of decomposition is carbonate of ammonia. 2 On the Fermentation of Urine: Reply to M. Pasteur. By Prof. H. C.
Bastian.
M. Pasteur desires $\left(110^{\circ} \mathrm{C}\right.$.), there is absolutely no reason for substituting solid potash as he has done. The liquor potassce used by me has always been procured from Mr. Wm. Martindale, of ro, New Cavendish Street, London.

In his "Note" of July 17 , the interpretation given by M. Pasteur of my results was that the liquor potassa used by me immediately after it had been heated to $100^{\circ} \mathrm{C}$. induced fermentation in the urine because it contained living germs not killed at this temperature of $100^{\circ} \mathrm{C}_{\text {, }}$, but which would have been killed had the potash solution been heated to $I \mathrm{IO}^{\circ} \mathrm{C}$. M. Pasteur has strangely understood my meaning if he thinks, as he now intimates, that $I$ have not contested the legitimacy of his reasoning. I am very far from regarding it as "irreproachable," and that for reasons which I have previously given. If, however, I have not been able to make myself understood it will be well for me to repeat the reasons on account of which I still absolutely reject M. Pasteur's interpretation. They are these:-(I) It is to me incredible that a fluid so caustic as the strong liquor potassæ which I have employed could contain living germs after it has been raised to $100^{\circ} \mathrm{C}$., and it is not too much to ask that he who makes such an assertion should prove it ; (2) that liquor potassa (wohen added in proper quantity to the urine) is just as efficacious after it has been heated to $x 10^{\circ} \mathrm{C}$. as when it has only been heated to $100^{\circ} ;(3)$ the decisive proof that liquor potassee previously heated to $100^{\circ}$ does not induce fermentation in sterile urine by reason of its containing living germs, is to be found in the fact that the addition of one or two drops of it only (when much more would be required for neutralisation), subsequently leaves the urine as barren as if no solution of potash had been added; whilst if the liquor potassæe really induced fermentation in the cases mentioned above (2) because of its containing living germs, then one or two drops of it would always suffice to infect any quantity of sterile urine to which they may have been added.

In his last communication to the Acaderny, M. Pasteur says :- "La question se trouve donc limitée à la connaissance de ce point:-Ai-je fait autre chose que de remplacer la potasse en solution par de la potasse fondue, et notablement, ai-je depassé le point de saturation de l'urine, et $\mathrm{y}$ a.t-il quelque inconvénient à le faire?" To these three questions I reply as follows :--(I) Yes, too much potash was also added; (2) Yes, in those experiments in which you obtained negative results, you expressly state that potash was added in quantity sufficient to render the fluid "alcaline" Compt. Rend. t. lxxxiii. pp. 179 and 377 ; (3) Yes, according to my experience, any amount of potash beyond what is sufficient to neutralise the urine in its unboiled state is decidedly prejudicial to the inducement of fermentation, and I have especially cautioned experimentalists on this subject (see Froceedings of Royal Society, No. I72, pp. 152 notet, and 155 .

I would also call M. Pasteur's attention to the fact that in his last communication to the Academy, as printed in the Compt. Rend. for January 8, on the two occasions on which he professes to describe my experiment, he does it inaccurately. Thus, on p. 65 , lines 2 and 3 , and also on p. 66 , in the sixth line from the termination of his note, he omits to mention the important fact that the added liquor potasse was previously boiled.

Further discussion between M. Pasteur and myself seems to me in the present phase of the question to be almost useless. Certainly, no good can come from our alternate enunciation of opposite experimental results, when precisely the same methods have not been had recourse to. For my own part I am perfectly ready to reproduce before competent witnesses the results of which $I$ have above spoken; or, failing this opportunity, $I$ shall also be content patiently to awalt the ultimate decision of other properly informed fellow investigators, both here and on the Continent, as to the correctness of the facts which I have had the honour of announcing to the Academy.

\section{ҰOHANN CHRISTIAN POGGENDORFF}

CCIENCE has lost one of her most diligent and devoted servants by the death of Prof. Dr. J. C. Poggendorff, in Berlin, on January 24. He was born in Hamburg on December 29, I796. The early deaths of both parents forced him at a comparatively tender age to engage in the rougher conflicts of life; a circumstance which, however, contributed in a great measure to the rapid development and maturity of his 